\title{
Kettős röntgensugár abszorpciós eljáráson és bioelektromos impedancián alapuló testösszetétel-becslö módszerek összehasonlító elemzése fiatal sportolók körében
}

\section{Comparison of body composition estimates from dual X-ray absorptiometry and bioimpedance analysis in young athletes}

\author{
Utczás Katinka, Tróznai Zsófia, Pálinkás Gergely, Kalabiska Irina, Petridis \\ Leonidas
}

Testnevelési Egyetem, Sportélettani Kutató Központ

\begin{abstract}
Absztrakt - A testösszetétel-becslés során más-más módszerekkel kapott eredmények eltéróek lehetnek, ezért értelmezésükhöz, elemzésükhöz kelló óvatosság szükséges, föleg sportolók esetében, ahol a legkisebb testösszetételbeli különbségek is hatással lehetnek a teljesítményre. Vizsgálatunk célja, hogy elemezzük két, napjainkban elterjedt testösszetételt meghatározó módszer eredményei közötti eltéréseket fiatal sportolóknál. Mintánkban 1004 13-18 év közötti sportoló gyermek testösszetételét határoztuk meg bioelektromos impedancián alapuló módszer (BIA), valamint kettős röntgensugár abszorpciós eljárás (DEXA) segítségével. A kapott értékek közötti kapcsolatot korrelációval, az eltéréseket két mintás t-próbával, páros t-próbával, illetve Bland-Altman analízis segítségével elemeztük, 5\%-os szignifikancia szinten. A két módszerrel becsült testösszetevó komponensek között erós korrelációt találtunk a zsírtömeg és a sovány tömeg esetében ( $r 2=0,873, p<0,05$, illetve $r 2=0,964, p<0,05)$. A vizsgálat során azt tapasztaltuk, hogy a BIAval meghatározott zsírtömeg és zsírszázalék szignifikánsan kisebb (fiú/leányok: 4,9/4,6 kg-mal, illetve 7,1/7,2 \%-kal), míg a sovány tömeg szignifikánsan nagyobb értéket mutatott (fiúk/leányok: 3,8/3,8 kg-mal), mint a DEXA-val mért eredmények. A nemek között az átlagos eltérések mértéke nem különbözött egyik vizsgált paraméter esetében sem. A különbségek hátterében egyrészt a két módszer alapvetően eltérő múködési elve (DEXA: röntgensugár elnyelődése a különböző súrúségú szövetekben; BIA: szövetek eltérő víztartalma miatti vezetőképességbeli különbségek), másrészt a sportolók átlagos populációtól eltéró testösszetétele állhat. Úgy túnik, hogy a kisebb zsírszázalék esetén nagyobb a különbség a két módszer által becsült értékek között.
\end{abstract}

Kulcsszavak: testösszetétel-becslés, BIA, DEXA, utánpótlás sport

\begin{abstract}
Results obtained by different methods in body composition assessments may differ significantly. So the interpretation of results should be treated with caution. This is especially important in athletes when even small changes in body composition may influence athletic performance. The aim of our study was to analyze the differences between the results of two common methods of body composition analysis in young athletes. Our sample consisted of 1004 athletes aged 13-18 years. Their body composition was measured by bioimpedance (BIA) and by dual X-ray absorptiometry methods (DEXA). Differences between subgroups were analyzed by two sample t-tests, paired t-tests, and Bland-Altman analysis. Pearson correlation was used to look for relationships between the examined variables. There was a strong correlation between the results of the two methods for fat mass and lean mass ( $r 2=0.873, p<0.05$ and $r 2=0.964, p<0.05$ respectively). Fat mass and fat percentage measured by BIA were significantly lower (boys/girls by 4.9/4.6 $\mathrm{kg}$ and by 7.1/7.2 \% respectively), while lean body mass was significantly higher (boys/ girls by $3.8 / 3.8 \mathrm{~kg}$ respectively), than the results measured by DEXA. The magnitude of mean differences did not differ for any of the examined parameters between boys and
\end{abstract}


girls. On the one hand, the differences may be attributed to the fundamentally different operating principle of the two methods and on the other hand to the body composition traits observed in athletes. Lower fat percentage results in larger differences between the two methods.

Keywords: body composition estimate, BIA, DEXA, youth athletes

\section{Bevezetés}

Sportolók körében általánosan jellemzö, hogy az átlag populációhoz képest kevesebb zsírszázalékkal és nagyobb izomszázalékkal rendelkeznek. Azonban más-más testösszetételi arányok jellemzőek a különböző sportágakra, az egyes posztokra, valamint a testösszetevő komponensek mennyisége és aránya az életkorral is változik (Malina és Geithner, 2011). Tapasztalataink alapján az élsportban a legkisebb különbségnek is van jelentősége, ezért szükséges ismerni a sportágakra, bizonyos esetekben a posztokra jellemző testösszetételt.

Manapság már számos lehetőség áll rendelkezésre a testösszetétel meghatározására: bioelektromos impedanciás (BIA), kettős röntgensugár abszorpciós (DEXA), ultrahangos, pletizmográfiás (ADP), illetve testméretek figyelembe vételével antropometriai becslőegyenletekre épülő módszerek (Toomey, Hughes és Norton, 2015). Ezek közül vannak olyanok, melyek használata széles körben elterjedt; megtalálhatjuk egészségügyi központokban, iskolákban, sportlétesítményekben és vannak olyanok, melyekkel csak néhány laboratóriumban, illetve kórházban találkozhatunk. A hozzáférhetőségen túl széles skálán változik egy-egy vizsgálat költségigénye, továbbá hogy alkalmazása igényel-e szakképzettséget, valamint hogy invazív-e az eljárás. Referencia módszernek a mágneses rezonancia vizsgálatot (MRI), a computer tomográfiás eljárást $(\mathrm{CT})$ és a négy komponensü modellt (4-C) tekintik (Ackland, Lohman, Sundgot-Borgen, Maughan, Meyer, Stewart és Müller, 2012). A 4-C modell a test tömegének, térfogatának, teljes víztartalmának, illetve a csont ásványai anyag tartalmának ismeretében egy egyenlet segítségével számítja ki a zsírtömeget. A különböző változókat tipikusan azok meghatározására szolgáló műszerekkel mérik, így a test térfogatát pletizmográfiás eljárással, a test teljes víztartalmát víz alatti tömegméréssel, vagy BIA-val, a csont ásványi anyag tartalmát pedig DEXA-val (Ackland és mtsai, 2012; Wells, Williams, Chomotho, Darch, Grijalva-Eternod, Kennedy, Haroun, Wilson, Cole és Fewtrell, 2012; Williams, Wells, Wilson, Haroun, Lucas és Fewtrell, 2006).

Több tanulmány is foglalkozott a különbözö testösszetételt meghatározó módszerek eredményeinek összehasonlításával. Egyrészt vizsgálták a referencia módszer (4-C modell) által meghatározott és a DEXA-val mért értékek különbségeit (Wells és mtsai, 2012; Williams és mtsai, 2006). Hasonlóképp elemezték a BIA-val kapott és a 4-C modell segítségével számított eredmények közötti eltérések mértékét (Jebb, Siervo, Murgatotroyd, Evans, Früchbeck és Prentice, 2007). Másrészt több módszer egyidejü összehasonlítását is elvégezték. Egyesek testméretek alapján becsült zsírszázalék eredményeit vetették össze műszeres technikával (DEXA, BIA) mért értékekkel (Aandstad, Holtberget, Hageberg, Holme és Anderssen, 2014; Gutin, Litaker, Aslam, Smith és Treiber, 1996). Mások a testösszetétel-becslő műszerek (DEXA, BIA, ADP) eredményei közötti különbségeket elemezték (Hurst, Walsh, Conlon, Ingram, Kruger és Stonehouse, 2016; Tompuri, Lakka, Hakulinen, Lindi, Laaksonen, Kilpeläinen, Jääskeläinen, Lakka és Laitinen, 2015).

A legtöbb esetben a vizsgálat alanyai nem sportoló gyermekek, valamint felnőttek voltak (Aandstad és mtsai, 2014; Hurst és mtsai, 2016; Leahy, O'Neill, Sohun és Jakeman, 2012; Ling, de Craen, Slagboom, Gunn, Stokkel, Westendrop és Maier, 2011; Sillanpää, Cheng, Häkkinen, Finni, Walker, Pesola, Ahtiainen, Stenroth, Selanne és Sipilä, 2014). Csak kevés vizsgálat során elemezték sportolók körében a különböző testösszetételbecslő módszerek eredményei közötti különbségeket (Esco, Snarr, Leatherwood, Chamberlain, Redding, Flatt, Moon és Willford, 2015; Knechtle, Wirth, Knechtle, Rosemann, Rüst, és Bescós, 2011). 
Az eredmények egyöntetűen arról számolnak be, hogy a különböző módszerek eltérő testösszetételi mennyiségeket állapítanak meg, azonban az eljárások között egy egyértelmű relációs sorrendet nem lehet felállítani (Fogelholm és Lichtenbelt, 1997).

Napjainkban az egyik leggyakrabban alkalmazott módszer a bioelektromos impedancián alapuló testösszetétel meghatározás, mivel könynyen, gyorsan és alacsony költségek mellett kapunk megfelelően pontos eredményt (Bedogi, Malavolti, Severi, Poli, Mussi, Fantuzzi és Battistini, 2002). Mindezen tulajdonságai miatt kaphat kiemelt szerepet az iskolai fittségi felmérések során is (Csányi, Finn, Welk, Zhu, Karsai, Ihász, Vass és Molnár, 2015). Az elmúlt években azonban egyre gyakrabban fordul elö, hogy kettős röntgensugár abszorpciós eljárással határozzák meg a testösszetevő komponensek mennyiségeit, valamint testtömegen belüli arányukat (Toombs, Ducher, Shepherd és De Souza, 2012).

Mindezek alapján célunk volt elemezni fiatal sportolók körében azt, hogy milyen kapcsolat van a BIA és DEXA által mért testösszetevő komponens-értékei között. Továbbá célunk volt, hogy vizsgáljuk ezeknek az eltéréseknek irányát, illetve nagyságát.

\section{Anyag és módszer}

Vizsgálatunkban összesen 14 sportág (cselgáncs, kajak-kenu, kerékpár, öttusa, labdarúgás, birkózás, kosárlabda, kézilabda, vívás, úszás, jégkorong, evezés, ritmikus sportgimnasztika és súlyemelés) 13-18 év közötti sportolója vett részt, akik átlagosan 7,2 $\pm 2,5$ évesen kezdtek el sportolni jelenlegi sportágukban és a vizsgálat időszakában 10,2 $\pm 3,7$ órát edzettek egy héten. A gyermekek mind valamely magyarországi akadémia, illetve egyesület igazolt sportolói. A felmérés során rövid antropometriai protokollt követően vettek részt a két különböző módszerrel történő testösszetétel meghatározáson. A vizsgálatokat egy napon, maximum 3 órás eltéréssel végeztük. A sportolók először a bioelektromos impedancián alapuló vizsgálatra mentek, ezt követően végeztük el a DEXA vizsgálatot. A vizsgáltban részt vett sportolók jellemzőit együttesen, illetve nemenként feltűntetve az 1. táblázat tartalmazza.

1. táblázat A vizsgált sportolói minta jellemzői (átlagさszórás)

\begin{tabular}{|c|c|c|c|}
\hline & Teljes & Fiúk & Leányok \\
\hline & $\mathrm{n}=1004$ & $\mathrm{n}=824$ & $\mathrm{n}=180$ \\
\hline Decimális kor (év) & $15,8 \pm 1,4$ & $15,9 \pm 1,4$ & $15,4 \pm 1,4$ \\
\hline Testmagasság (cm) & $177,3 \pm 9,4$ & $178,5 \pm 9,2$ & $171,4 \pm 8,0$ \\
\hline Testtömeg (kg) & $66,9 \pm 11,9$ & $67,6 \pm 11,8$ & $63,6 \pm 11,8$ \\
\hline Edzéskor (év) & $8,7 \pm 2,8$ & $9,1 \pm 2,8$ & $7,1 \pm 2,4$ \\
\hline Edzésszám (óra/hét) & $10,2 \pm 3,7$ & $10,1 \pm 3,2$ & $10,5 \pm 5,4$ \\
\hline
\end{tabular}

\section{Antropometria}

A sportolók testméreteit standard műszerekkel, a Nemzetközi Biológiai Program (IBP) által ajánlott Martin-féle módszer szerint vettük fel (Martin és Saller, 1957; Weiner és Lourie, 1969). A testméretek közül csak a testmagasság, valamint a testtömeg értékei kerültek be a tanulmányban bemutatott elemzésekbe. A testmagasságot standard antropométerrel (DKSH Switzerland Ltd, Zürich, Svájc) milliméter pontossággal, a testtömeget digitális mérleg (Seca) segítségével 0,1 kilogramm pontossággal mértük.

\section{Bioelektromos impedanicia analizis (BIA)}

A vizsgálat során InBody 720 (Biospace Co., Seoul, Korea) típusú müszerrel dolgoztunk, amely 8 pont között méri a bőrellenállás mértékét. Ezzel a technikával lehetőség nyílik arra, hogy a test összetevőit nemcsak összességében, de szegmentálisan is elemezhessük. A műszer a különböző frekvenciákon $(1 \mathrm{kHz}, 5 \mathrm{kHz}, 50 \mathrm{kHz}$, $250 \mathrm{kHz}, 500 \mathrm{kHz}, 1 \mathrm{MHz}$ ) mért ellenállások alapján regressziós egyenletek segítségével határozza meg a testösszetevők mennyiségét, figyelembe véve azt a tényt, hogy a különböző szövetek 
más-más mértékben tartalmaznak vizet (izomszövet $\sim 80 \%$, zsírszövet $-15 \%$ csontszövet $\sim 40 \%$ ), így vezetőképességük is eltérő (Kushner, 1992). A műszer meghatározza a test teljes víztartalmát (l) külön extra- és intracelluláris folyadékra bontva, a fehérje- $(\mathrm{kg})$, az ásványi anyag- (kg) és a zsír tömegét $(\mathrm{kg})$. Emellett a műszer megadja a zsír$(\mathrm{kg})$ és sovány tömeget $(\mathrm{kg})$ a test egészére, illetve a törzsre és a végtagok szegmenseire egyaránt (Bedogi és mtsai, 2002).

\section{Kettös röntgensugár abszorpciometria (DEXA)}

A vizsgálathoz Lunar Prodigy típusú DEXA (General Electric, Madison, USA) berendezést használtunk. A mérés során két eltérő energiával (magas és alacsony) rendelkező röntgensugár halad át a testen. A szöveten való áthaladáskor, annak sűrűségétől és vastagságától függően csökken a fotonsugár intenzitása. A műszer területegységeket (pixelek) vizsgál, elkülöníti a csontot tartalmazó és nem tartalmazó egységeket, mely így lehetővé teszi a csont és a lágyszöveti összetevők mennyiségi meghatározását (Toombs és mtsai, 2012). A szoftver automatikusan meghatározza a régiónkénti (törzs, jobb kar, bal kar, jobb alsó

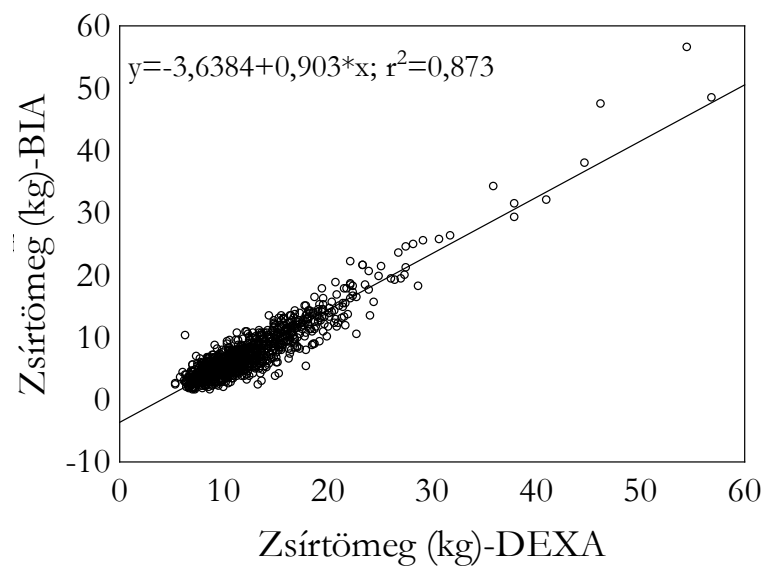

végtag, bal alsó végtag) csontásványi anyag tartalmát (BMC), zsírtömegét, valamint sovány tömegét grammnyi pontossággal.

\section{Statisztikai elemzések}

A kapott eredményeket Statistica 13.5 programcsomag segítségével elemeztük. A műszerek által mért azonos testösszetevők közötti kapcsolatot korrelációs együtthatóval (Pearson-féle) jellemeztük. A testösszetevő komponensek különböző módszerek által becsült értékeinek összehasonlítására a Bland-Altman analízist (Bland és Altman, 1986), valamint a páros t-próbát, a nemek közötti különbségek kimutatására pedig kétmintás t-próbát használtunk. A szignifikancia szintet $\mathrm{p}<0,05$ határoztuk meg.

\section{Eredmények}

Összességében kijelenthetjük, hogy a BIA és DEXA módszerrel becsült testösszetevő komponensek értékei között erős összefüggést találtunk (1. ábra). A teljes test vizsgálatakor a sovány tömeg esetében az $\mathrm{r}^{2}=0,964$, míg a zsírtömegé $\mathrm{r}^{2}=0,873$ volt. A szegmentális sovány tömeg meghatározásakor $0,848 \leq \mathrm{r}^{2} \leq 0,883$ között változtak.

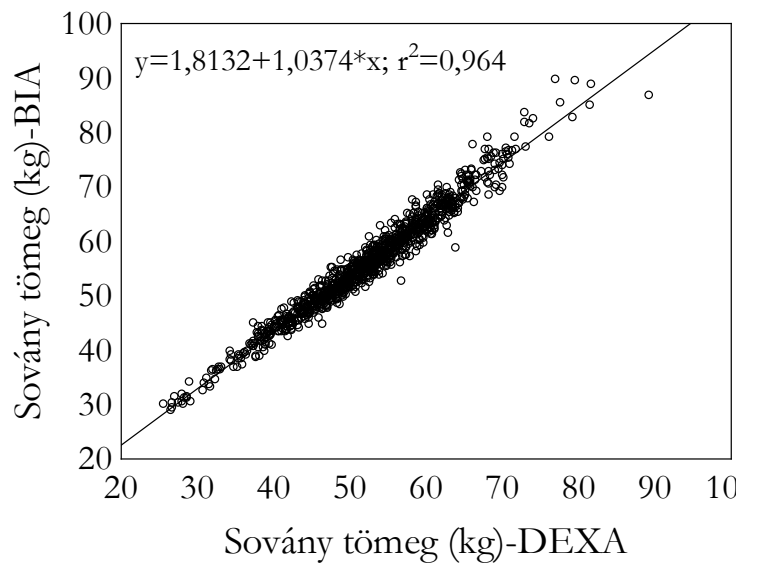

1. ábra DEXA és BIA által meghatározott a) zsírtömeg és b) sovány tömeg értékek közötti kapcsolat

A fiúk és leányok között szignifikáns különbséget $(\mathrm{p}<0,01)$ tapasztaltunk a testösszetevők mennyiségében és arányában. A leányok szignifikánsan nagyobb zsírtömeggel, valamint zsírszázalékkal és szignifikánsan kisebb sovány tömeggel rendelkeztek a vizsgált csoportban. A két módszer által meghatározott zsírtömeg, zsírszázalék és sovány tömeg értékek között szignifikáns különbséget $(\mathrm{p}<0,01)$ találtunk, összességében és nem szerinti bontásban egyaránt. A bioelektromos impedancián alapuló módszer kisebbnek becsülte a zsír tömegét és a testtömegen belüli arányát, míg a sovány tömeget nagyobbnak határozta meg mind a fiúknál, mind a leányoknál (2. táblázat). 
A differenciák átlagos eltérései között nem volt különbség a két nem között. A fiúknál a BIA átlagosan 4,9 kg-mal, míg a leányoknál 4,6 kg-mal kevesebbnek határozta meg a zsírtömeg értékét, mint a DEXA. A fiúknál átlagosan 7,1\%-kal,

a)

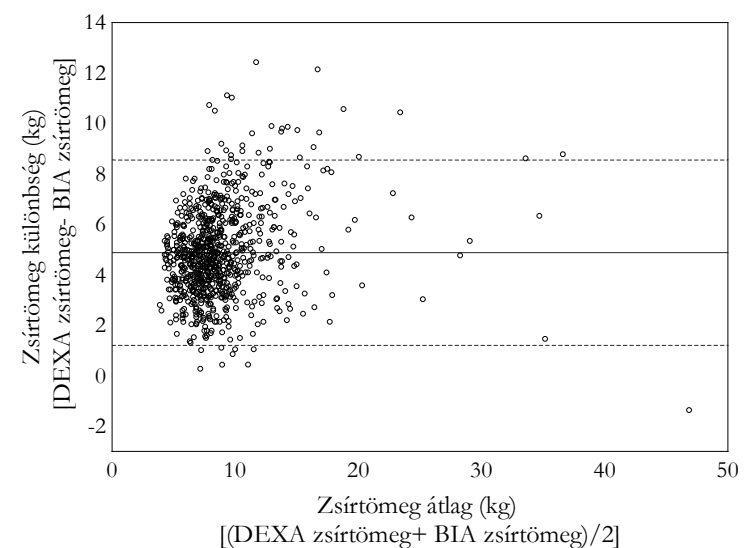

b)

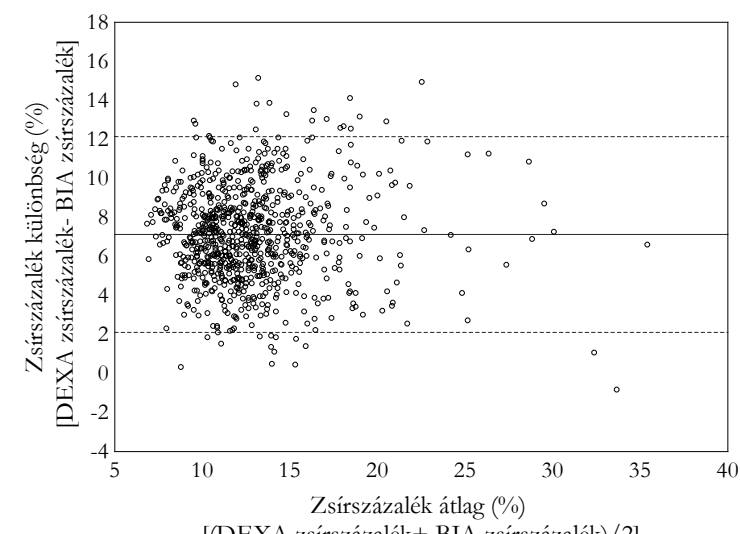

c)

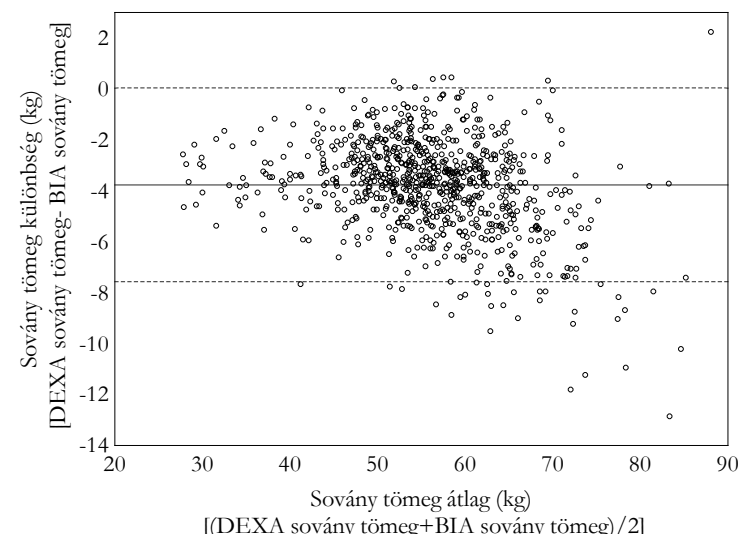

leányoknál 7,2\%-kal volt kisebb a bioelektromos impedanciás készülékkel mért zsírarány. A sovány tömeg esetében mindkét nemnél egyaránt $3,8 \mathrm{~kg}$ volt az átlagos különbség a két módszer között (2. ábra).
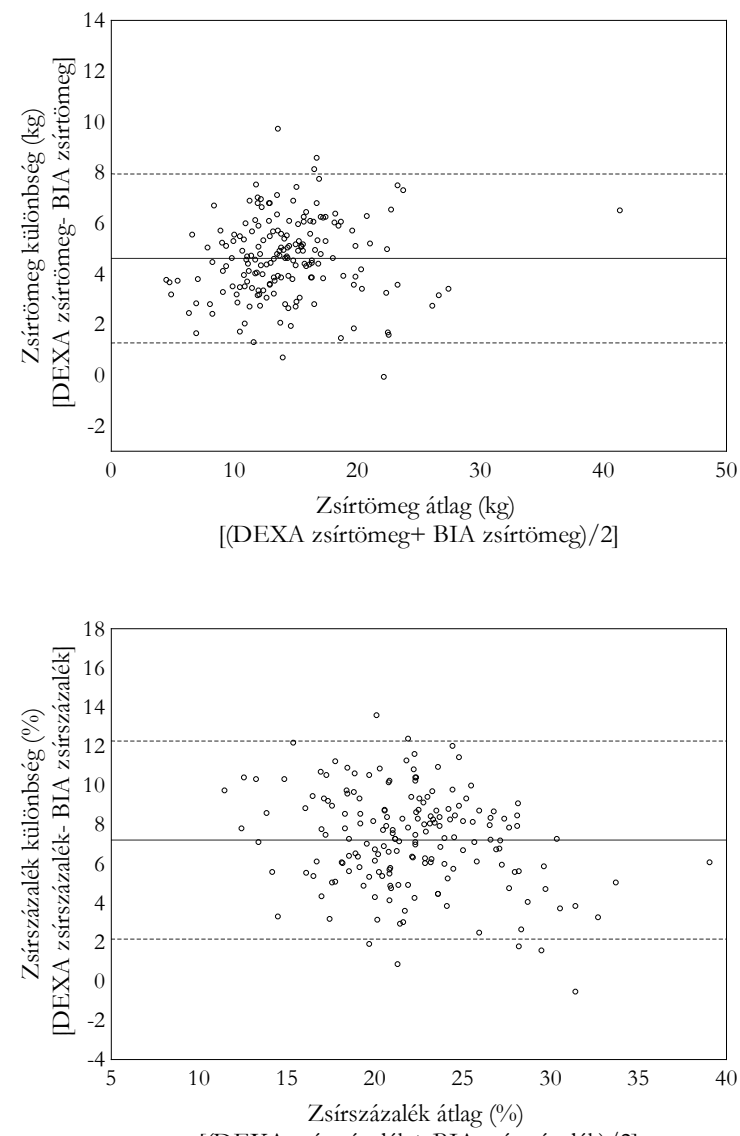

[(DEXA zsírszázalék+ BIA zsírszázalék)/2]

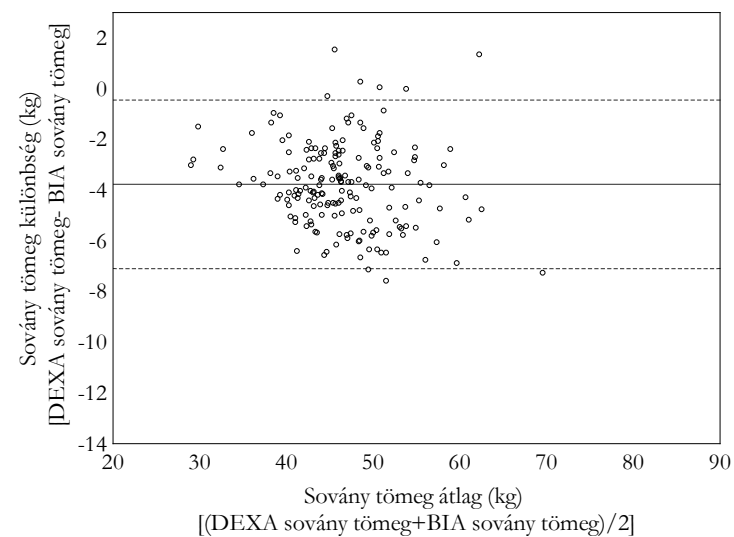

[(DEXA sovány tömeg+BIA sovány tömeg) /2]

2. ábra A DEXA és BIA eredményeinek átlagos különbsége nemenként Bland-Altman analízissel. A folytonos vonal a különbségek átlagát, a szaggatott vonal a \pm 2 szórást mutatja. a) zsírtömeg (kg); b) zsírszázalék (\%); c) sovány tömeg $(\mathrm{kg})$ 
A szegmentális sovány tömeg vizsgálatakor hasonló tendenciákat figyeltünk meg, mint a teljes testnél. A fiúk minden szegmensben szignifikánsan nagyobb sovány tömeggel rendelkeztek, mint a leányok, továbbá a DEXA-val szignifikánsan kisebb eredményeket kaptunk, mint a BIA-val történt becsléskor (3. táblázat). Az átlagos eltérések mértékében azonban különbségeket találtunk a nemek között. Míg a felső végtagoknál szignifikánsan nagyobb volt a differencia mértéke a leányoknál, addig az alsó végtagoknál a fiúknál tapasztaltunk nagyobb különbséget a műszerek által becsült testösszetevő komponens között. A törzs esetében nem volt különbség az eltérések mértékében a két nem között.

2. táblázat A DEXA és BIA módszerrel meghatározott testösszetevők értékei nemenként (átlag₫szórás)

\begin{tabular}{|c|c|c|c|c|c|c|}
\hline & \multicolumn{2}{|c|}{ Teljes } & \multicolumn{2}{c|}{ Fiúk } & \multicolumn{2}{c|}{ Leányok } \\
\hline & DEXA & BIA & DEXA & BIA & DEXA & BIA \\
\hline Zsírtömeg $(\mathrm{kg})$ & $12,3 \pm 5,1$ & $7,5 \pm 4,9^{*}$ & $11,3 \pm 4,1$ & $6,4 \pm 3,7^{*}$ & $17,0 \pm 6,3^{\dagger}$ & $12,4 \pm 6,3^{* \dagger}$ \\
\hline Zsírszázalék $(\%)$ & $18,1 \pm 5,4$ & $10,9 \pm 5,5^{*}$ & $16,4 \pm 3,8$ & $9,2 \pm 3,8^{*}$ & $25,9 \pm 4,6^{\dagger}$ & $18,7 \pm 5,4^{* \dagger}$ \\
\hline Sovány tömeg $(\mathrm{kg})$ & $52,4 \pm 9,1$ & $56,2 \pm 9,7^{*}$ & $54,1 \pm 8,8$ & $57,9 \pm 9,4^{*}$ & $44,6 \pm 6,1^{\dagger}$ & $48,4 \pm 6,4^{* \dagger}$ \\
\hline
\end{tabular}

DEXA: kettös röntgensugár abszorpciós eljárás (Lunar Prodigy); BIA: bioelektromos impedancián alapuló módszer (InBody 720); *p<0,01; szignifikáns különbségek a müszerek által mért értékek között páros t-próbával; ${ }^{\dagger} p<0,01$; szignifikáns különbségek a nemek között kétmintás t-próbáva

3. táblázat A DEXA és BIA módszer által meghatározott szegmentális sovány tömeg eredmények nemenként (átlag \pm szórás)

\begin{tabular}{|c|c|c|c|c|c|c|}
\hline & \multicolumn{2}{|c|}{ Teljes } & \multicolumn{2}{c|}{ Fiúk } & \multicolumn{2}{c|}{ Leányok } \\
\hline & DEXA & BIA & DEXA & BIA & DEXA & BIA \\
\hline Jobb $k a r(\mathrm{~kg})$ & $3,2 \pm 0,8$ & $3,3 \pm 0,8^{*}$ & $3,3 \pm 0,7$ & $3,4 \pm 0,7^{*}$ & $2,4 \pm 0,4^{\dagger}$ & $2,7 \pm 0,5^{* \dagger}$ \\
\hline Bal kar $(\mathrm{kg})$ & $3,0 \pm 0,7$ & $3,2 \pm 0,8^{*}$ & $3,2 \pm 0,7$ & $3,3 \pm 0,7^{*}$ & $2,3 \pm 0,4^{\dagger}$ & $2,6 \pm 0,5^{* \dagger}$ \\
\hline Törzs $(\mathrm{kg})$ & $24,9 \pm 4,3$ & $25,7 \pm 4,5^{*}$ & $25,7 \pm 4,2$ & $26,4 \pm 4,4^{*}$ & $21,6 \pm 2,8^{\dagger}$ & $22,3 \pm 3,0^{* \dagger}$ \\
\hline Jobb alsó végtag $(\mathrm{kg})$ & $9,1 \pm 1,7$ & $9,6 \pm 1,8^{*}$ & $9,4 \pm 1,7$ & $9,9 \pm 1,7^{*}$ & $7,7 \pm 1,3^{\dagger}$ & $8,0 \pm 1,3^{* \dagger}$ \\
\hline Bal alsó végtag $(\mathrm{kg})$ & $9,0 \pm 1,7$ & $9,5 \pm 1,8^{*}$ & $9,3 \pm 1,7$ & $9,9 \pm 1,7^{*}$ & $7,6 \pm 1,3^{\dagger}$ & $8,0 \pm 1,3^{* \dagger}$ \\
\hline
\end{tabular}

DEXA: kettös röntgensugár abszorpciós eljárás (Lunar Prodigy); BIA: bioelektromos impedancián alapuló módszer (InBody 720); ${ }^{*}<<0,01 ;$ szignifikáns különbségek müszerek által becsült testösszetevök között páros t-próbával; ${ }^{\dagger} p<0,01$; szignifikáns különbségek nemek között kétmintás t-próbával

\section{Megbeszélés és következtetések}

Vizsgálatunk célja volt összehasonlítani két, napjainkban elterjedt testösszetételt meghatározó műszer eredményeit sportoló fiúk és leányok körében. Tanulmányoztuk a BIA és DEXA által mért eredmények közötti különbségek mértékét nemenként. Továbbá vizsgáltuk a sovány tömeg esetében az egész test elemzésén túl az egyes szegmenseire kapott eltérések nagyságát.

A vizsgálatban alkalmazott módszerek irodalmi adatok alapján érvényesek és jó megbízhatósággal

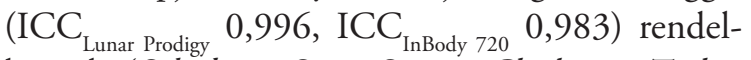
keznek (Schubert, Seay, Spain, Clarke és Taylor, 2018). Így mindkét eljárás alkalmas a testösszetétel meghatározására. Mindkét módszernek vannak előnyei és limitáló tényezői. A DEXA-val gramm pontossággal határozhatók meg az egyes testösszetevők, azonban csak laboratóriumi körülmények között lehet végezni a vizsgálatokat. Ezen kívül évi maximum 4 alkalommal javasolják a vizsgálat elvégzését, hiszen ha nagyon alacsony mértékben is, de sugárzásnak teszi ki a vizsgált személyeket (Tanner és Gore, 2013). A BIA-nak nagy előnye, hogy hordozható, így használható terep munkák során, illetve követéses vizsgálatokra is kiválóan alkalmas. Ugyanakkor a mérések eredményeit erősen befolyásolja a szervezet aktuális hidratáltsági állapota, így a mérések során nagyon kell ügyelni a 
pontos protokoll (vizsgálat elötti folyadék-fogyasztás, fizikai aktivitás) betartására (Ackland és mtsai, 2012).

A korábbi hasonló kutatások eredményei is egyöntetűen azt a megállapítást teszik, hogy a bioelektromos impedancia elvén müködő készülékek alulbecsülik a zsír tömegét és testtömegen belüli arányát, ezzel szemben nagyobbnak határozzák meg a sovány testtömeget (Esco és mtsai, 2015; Sillanpää és mtsai, 2014; Völgyi, Tylavsky, Lyytikäinen, Suominen, Alén és Cheng, 2008).

Sillanpää, Häkkinen és Häkkinen (2013) 18 és 88 év közötti felnőtteknél azt tapasztalták, hogy a zsírtömeg átlagos eltérése nőknél 3,1 kg (4,7\%), férfiaknál 2,6 kg (3,1\%), és a két módszer eredményei közötti eltérések minden életkorban szignifikánsak voltak. Utóbbi munkában a különbségek mértéke elmarad az általunk kapott eredményektől, aminek hátterében az állhat, hogy a vizsgálatban részt vevő alanyok zsírszázaléka lényegesen magasabb volt (férfiak: 22,2\%, nők: 31,7\%), mint az általunk vizsgált sportolói minta esetében. Ugyanis egyes tanulmányok a tápláltsági állapot hatásait vizsgálva azt tapasztalták, hogy az átlagos eltérések mértéke függ a nemtől, valamint a tápláltsági állapottól és elsősorban a nagyobb zsírtömegtől. Normál, túlsúlyos és obez tápláltsági csoportok között elemezték az eltérések mértékét. A BMI növekedésével mindkét nemnél csökkent a két műszer által meghatározott zsírszázalék közötti differencia mértéke (férfiak/nők: normál:5,8\%/5,9\%, túlsúlyos: $4,3 \% / 5,0 \%$, obez: $1,6 \% / 3,1 \%)$. Obez férfiaknál azt tapasztálták, hogy már nincs szignifikáns különbség a BIA és DEXA által mért értékek között (Völgyi és mtsai, 2008).

$\mathrm{Az}$ eltérések mértéke alapján eredményeink leginkább Esco és mtsai (2015) által leírt tapasztalatokkal voltak összhangban (DEXA/InBody ${ }_{720}$ sovány tömeg: 46,1 kg/48,2 kg; zsírszázalék: $26,9 \% / 22,5 \%)$. Ami talán annak tulajdonítható, hogy mindkét esetben a vizsgált személyek mindegyike sportoló volt, továbbá az általunk és általuk alkalmazott müszerek típusa megegyezett.

Esetünkben a Bland-Altman analízis során tapasztalt nagyobb átlagos eltérések (zsírtömeg fiú/ leány: 4,9 kg/4,6 kg; zsírszázalék: 7,2\%/7,1\%; sovány testtömeg: $3,8 \mathrm{~kg} / 3,8 \mathrm{~kg}$ ) hátterében $\mathrm{az}$ átlagos populációtól eltérő testösszetétel állhat. Ebben az életkorban (15-16 év) az átlagos magyar gyermek populációra jellemző zsírszázalék értékek
- melyet bioelektromos impedanciás készülékkel (InBody 720) határoztak meg - fiúk esetében -13\%, míg leányok esetében $-23 \%$ (Zsákai, Fehér, Annár és Bodzsár, 2017). Mivel a sportolók zsírértékei láthatóan elmaradnak az átlag populációtól, így ez nagyobb különbségeket eredményez a műszerek mérési eredményei között.

A szegmentális elemzéseket tartalmazó tanulmányokban az eredmények változóak. Bizonyos esetekben még az is előfordul, hogy az eddig általánosan tapasztaltakkal szemben DEXA-val nagyobbnak határozták meg a sovány tömeg értékét egyes szegmensekben (Tompuri és mtsai, 2015). Ennek oka lehet, hogy a kisebb tömegű szegmensek vizsgálatakor a teljes testnél kumulálódott különbségek nem tapasztalhatók olyan mértékben, hogy egyértelmü, konzekvens megállapításokat tehessünk.

Megjegyzendő, hogy ugyanazon elven müködő két műszer által becsült értékek között is lehet eltérés. Sheperd, Fan, $\mathrm{Lu}$, Wu, Wacker, Ergun és Levine (2012) megállapították, hogy két eltérő típusú (Lunar Prodigy és Hologic) DEXA készülék mérési eredményei között különbségek lehetnek. Jó korrelációs értékek mellett (zsírszázalék $\mathrm{r}=0,96)$, jelentős különbség volt a két müszer által becsült zsírszázalék értékek között. A Lunar típusú készülékkel felnőtteknél mintegy 2\%-kal $(\mathrm{p}<0,01)$ nagyobb zsírszázalékot mértek, mint a Hologic gyártású műszerrel. Hasonló vizsgálatot végeztek bioelektromos impedanciás készülékek között is. A DEXA által becsült zsírszázalék értékekhez hasonlítottak 1 frekvenciás 4 ponton (SF4), 1 frekvenciás 8 ponton (SF8) és multifrekvenciás 8 ponton (MF8) mérő készülékek eredményeit. A zsírszázalék átlagos eltérései a következők voltak: -3,5\% (SF4), $-2,7 \%$ (SF8) és - $0,1 \%$ (MF8) (Demura, Sato, és Kitabayashi, 2004).

Összefoglalva elmondható, hogy a testösszetétel mérés eredményei változhatnak az alkalmazott módszer, valamint az eszköz típusától függően. Napjainkban elterjedt testösszetételt meghatározó eljárások a BIA és a DEXA. Annak ellenére, hogy mindkettő megbízható vizsgálati módszer, mégis eltérö eredményeket szolgáltathatnak, ezért eredményeik nem felcserélhetők és helyettesíthetők egymással. Mindezek ismeretében a vizsgálatok tervezésekor a műszerek előnyei és limitáló tényezői mellett, figyelembe kell venni a vizsgálati minta jellemzőit is. Sportolóknál az alacsonyabb 
zsírszázalékból adódóan, úgy tünik, növekednek a különbségek a két módszer eredményei között. Így elemzésekkor ügyelni kell arra, hogy az eredményeket ugyanazon módszer referencia értékeivel hasonlítsuk össze, valamint ismételt mérések során mindig ugyanazzal a módszerrel dolgozzunk.

\section{Felhasznált irodalom}

1. Aandstad, A., Holtberget, K., Hageberg, R., Holme, I. és Anderssen, S.A. (2014): Validity and reliability of bioelectrical impedance analysis and skinfold thickness in predicting body fat in military personnel. Military Medicine 179. 2, 208-217. DOI: 10.7205/ MILMED-D-12-00545

2. Ackland, T.R., Lohman, T.G., SundgotBorgen, J., Maughan, R.J., Meyer, N.L.,. Stewart, A.D. és Müller, W. (2012): Current status of body composition assessment in sport. Sports Medicine 42. 3, 227-249. DOI: 10.2165/11597140-000000000-00000

3. Bedogi, G., Malavolti, M., Severi, S., Poli, M., Mussi, C., Fantuzzi A.J. és Battistini, N. (2002): Accuracy of an eight-point tactileelectrode impedance method in the assessment of total body water. European Journal Clinical Nutrition 56. 11, 1143-1148. DOI: 10.1038/ sj.ejcn. 1601466

4. Bland, J.M. és Altman, D.G. (1986): Statistical methods for assessing agreement between two methods of clinical measurement. Lancet 1. 307-310.

5. Csányi, T., Finn, K.J., Welk, G.J., Zhu, W., Karsai, I., Ihász, F., Vass, Z. és Molnár, L. (2015): Overview of the Hungarian national youth fitness study. Research Quarterly for Exercise and Sport 86. 1, 3-12. DOI: 10.1080/02701367.2015.1042823

6. Demura, S., Sato, S. és Kitabayashi, T. (2004): Percentage of total body fat as estimated by three automatic bioelectrical impedance analyzers. Journal of Physiological Anthropology and Applied Human Science 23. 3, 93-99. DOI: 10.2114/jpa.23.93

7. Esco, M.R., Snarr, R.L., Leatherwood, M.D., Chamberlain, N.A., Redding, M.L., Flatt, A.A., Moon, F.R. és Willford, H.N. (2015): Comparison of total and segmental body composition using DXA and multifrequency bioimpedance in collegiate female athletes.
Journal Strength and Conditioning Research 29. 4, 918-925. DOI: 10.1519/ JSC.0000000000000732

8. Fogelholm, M. és van Marken Lichtenbelt, W. (1997): Comparison of body composition methods: literature analysis. European Journal of Clinical Nutrition 51. 8, 495-503. DOI: 10.1038/sj.ejcn.1600448

9. Gutin, B., Litaker, M., Aslam, S., Smith, C. és Treiber, F. (1996): Body-composition measurement in 9-11-y-old children by dualX-ray absorptiometry, skinfold-thickness measurements, and bioimpedance analysis. American Society for Clinical Nutrition 63. 3, 287-292. DOI: 10.1093/ajcn/63.3.287

10. Hurst, P.R., Walsh, D.C.I., Conlon, C.A., Ingram, M., Kruger, R. és Stonehouse, W. (2016): Validity and reliability of bioelectrical impedance analysis to estimate body fat percentage against air displacement plethysmography and dual-energy X-ray absorptiometry. Nutrition \& Dietetics 73. 2, 197-204. DOI: 10.1111/1747-0080.12172

11. Jebb, S.A., Siervo, M., Murgatroyd, P.R., Evans, S., Früchbeck, G. és Prentice, A.M. (2007): Validity of the leg-to-leg bioimpedance to estimate changes in body fat during weight loss and regain in overweight women: comparison with multi-compartment models. International Journal of Obesity 31. 5, 756-762. DOI: 10.1038/sj.ijo.0803475

12. Knechtle, B., Wirth, A., Knechtle, P., Rosemann, T., Rüst, C.A. és Bescós, R. (2011): A comparison of fat mass and skeletal muscle mass estimation in male ultra-endurance athletes using bioelectrical impedance analysis and different anthropometric methods. Nutrición Hospitalaria 26. 6, 1420-1427. DOI: $10.1590 / S 0212-16112011000600032$

13. Kushner, R.F (1992): Bioelectrical impedance analysis: A review of principles and applications. Journal of the American College of Nutrition 11. 2, 199-209.

14. Leahy, S., O’Neill, C., Sohun, R. és Jakeman, P. (2012): A comparison of dual energy X-ray absorptiometry and bioelectrical impedance analysis to measure total and segmental body composition in healthy young adults. European Journal of Applied Physiology 112. 2, 589595. DOI: 10.1007/s00421-011-2010-4 
15. Ling, C.H.Y., de Craen, A.J.M., Slagboom, P.E., Gunn, D.A., Stokkel, M.P.M., Westendrop, R.G.J. és Maier, A.B. (2011): Accuracy of direct segmental multi-frequency bioimpedance analysis in the assessment of total body and segmental body composition in middle-aged adult population. Clinical Nutrition 30. 5, 610-615. DOI: 10.1016/j. clnu.2011.04.001

16. Malina, R.M. és Geithner, C.A. (2011): Body composition of young athletes. American Journal of Lifestyle Medicine 5. 3, 262-278. DOI: $10.1177 / 1559827610392493$

17. Martin, R. és Saller, K (1957): Lehrbuch der Anthropologie I-IV. Gustav Fischer Verlag, Stuttgart.

18. Schubert, M.M., Seay, R.F., Spain, K.K., Clarke, H.E. és Taylor, J.K. (2018): Reliability and validity of various laboratory methods of body composition assessment in young adults. Clinical Physiology and Functional Imaging 39. 2, 150-159. DOI: $10.1111 /$ cpf.12550

19. Sheperd, J.A., Fan, B., Lu, Y., Wu, X.P., Wacker, W.K., Ergun, D.L. és Levine, M.A. (2012): A multinational study to develop universal standardization of whole-body bone density and composition using GE Healthcare Lunar and Hologic DXA systems. Journal of Bone and Mineral Research 27. 10, 2208-2216. DOI: 10.1002/jbmr.1654

20. Sillanpää, E., Häkkinen, A. és Häkkinen, K. (2013): Body composition changes by DXA, BIA and skinfolds during exercise training in woman. European Journal of Applied Physiology 113. 9, 2331-2341. DOI: 10.1007/ s00421-013-2669-9

21. Sillanpää, E., Cheng, S., Häkkinen, K., Finni, T., Walker, S., Pesola, A., Ahtiainen, J., Stenroth, L., Selanne, H. és Sipilä, S. (2014): Body composition in 18- to 88-year-old adults comparison of multifrequency bioimpedance and dual-energy X-ray absorptiometry. Obesity 22. 1, 101-109. DOI: 10.1002/oby.20583

22. Tanner, R. K. és Gore, C. J. (2013): Assesment of Physique. In: Gary, S., Woolford, S. M. és Marfell-Jones, M. J. (szerk.): Physiological Test for Elite Athletes. Human Kinetics, USA, 167-198

23. Tompuri, T.T., Lakka, T.A., Hakulinen, M., Lindi, V., Laaksonen, D.E., Kilpeläinen, T.O.,
Jäskeläinen, J., Lakka, H.M. és Laitinen, T. (2015): Assessment of body composition by dual-energy X-ray absorptiometry, bioimpedance analysis and anthropometrics in children: the Physical Activity and Nutrition in Children Study. Clinical Physiology and Functional Imaging 35. 1, 21-33. DOI: 10.1111/cpf.12118

24. Toombs, R.J., Ducher, G., Shepherd, J.A. és De Souza, M.J. (2012): The Impact of Recent Technological Advances on the Trueness and Precision DXA to Assess Body Composition. Obesity 20. 1, 30-39. DOI: 10.1038/ oby.2011.211

25. Toomey, C., Hughes, K. és Norton, C. (2015): A review of body composition measurement in the assesment of health. Topics in Clinical Nutrition 30. 1, 16-32. DOI: 10.1097/ TIN.0000000000000017

26. Völgyi, E., Tylavsky, F.A., Lyytikäinen, A., Suominen, H., Alén, M. és Cheng, S. (2008): Assessing body composition with DXA and bioimpedance: effects of obesity, physical activity, and age. Obesity 16. 3, 700-705. DOI: 10.1038/oby.2007.94

27. Weiner, J.S. és Lourie, J.A., editors. (1969): Human biology. A guide to field methods. IBP Handbook. Oxford, Edinburgh: Blackwell Science.

28. Wells, J.C.K., Williams, J.E., Chomotho, S., Darch, T., Grijalva-Eternod, C., Kennedy, K., Haroun, D., Wilson, C., Cole, T.J. és Fewtrell M.S. (2012): Body-composition reference data for simple and reference techniques and a 4-component model: a new UK reference child. The American Journal of Clinical Nutrition 96. 6, 1316-1326. DOI: 10.3945/ajcn.112.036970

29. Williams, J.E., Wells, J.C.K., Wilson, C.M., Haroun, D., Lucas, A. és Fewtrell, M.S. (2006): Evaluation of Lunar Prodigy dualenergy X-ray absorptiometry for assessing body composition in healthy persons and patients by comparison with the criterion 4-component model. The American Journal of Clinical Nutrition 83. 5, 1047-1054. DOI: 10.1093/ajcn/83.5.1047

30. Zsákai, A., Fehér, V.P., Annár, D. és Bodzsár, É. (2017): A gyermek- és serdülőkori kövérség meghatározásának testzsírosság mutatóira épülő új hazai határértékei. Anthropologiai Közlemények 58. 63-74. 